\title{
Tecnura
}

\section{Applying MULTIPOL to Determine the Relevance of Projects in a Strategic IT Plan for an Educational Institution}

\section{Determinación de la pertinencia de proyectos de un plan estratégico informático en una institución educativa aplicando MULTIPOL}

\author{
Raúl José Martelo Gómez ${ }^{\circledR}$, Tomas José Fontalvo Herrera ${ }^{\circledR}$, \\ Carlos Alberto Severiche Sierra ${ }^{3}$
}

Fecha de recepción: 13 de febrero de 2020

Fecha de aceptación: 13 de Agosto de 2020

Cómo citar: Martelo Gómez., R.J. Fontalvo Herrera., T.J. y Severiche Sierra., C.A. (2020). Applying MULTIPOL to Determine the Relevance of Projects in a Strategic IT Plan for an Educational Institution. Tecnura, 24(66), 76-84. https://doi.org/10.14483/22487638.16176

\begin{abstract}
Objective: To determine the relevance of the projects defined in a strategic IT plan for an educational institution through the application of MULTIPOL.

Methodology: The research was quantitative with a descriptive non-experimental design. Interviews were conducted with teachers and administrators of the educational institution called "Cuarta Poza de Manga," as well as a documentary review, in order to determine the parameters required to apply MULTI$\mathrm{POL}$ and evaluate the more relevant projects of the institution.

Results: It was established that the most relevant projects for the institution were the following: Improving the computer infrastructure; incorporating an online learning management system to support teaching processes; using social media to broadcast relevant information to the educational community of the institution.
\end{abstract}

Conclusions: The application on MULTIPOL allowed finding the most relevant projects the institution should take into account to leverage its development. Keywords: strategic IT plan, educational institution, MULTIPOL, decision-making, pertinence.

\section{Resumen}

Objetivo: La presente investigación tuvo por objetivo determinar la pertinencia de los proyectos definidos en un plan estratégico informático de una institución educativa mediante la aplicación de MULTIPOL

Metodología: La investigación realizada fue de tipo cuantitativo con diseño no experimental transeccional descriptivo, donde se aplicó una revisión documental y entrevistas a docentes y administrativos de la Institución Educativa Cuarta Poza de Manga, con el fin de determinar los parámetros requeridos para aplicar MULTIPOL y evaluar los proyectos con aspectos relevantes a la institución.

1 Systems Engineer from the Industrial University of Santander. Specialist in Networks and Telecommunications from Industrial University of Santander; Master in Computer Science from the Industrial University of Santander. Full-time Research Professor of the Systems Engineering Program at the University of Cartagena. Leader of the INGESINFO Research Group-Category B of Colciencias. Cartagena de Indias, Colombia. E-mail: rmartelog1@unicartagena.edu.co

2 Chemical Engineer from the University of Atlántico, with a Specialization in Finance and Systems. Master in Business Administration from the University of la Costa. Full-Time Research Professor at the University of Cartagena. Leader of the Calidad y Productividad Organizacional group. Cartagena de Indias, Colombia. E-mail: tfontalvoh@unicartagena.edu.co

3 Doctor of Science (Mention: Management), Magister in Sustainable Development and Environment, Specialist in Safety and Health at Work, Specialist in Sanitary and Environmental Engineering, Chemist, Health Services Administration. Minuto de Dios University Corporation-UNIMINUTO. Barranquilla, Colombia. carlos.severiche@uniminuto.edu.co 
Resultados: Se estableció que los proyectos con mayor pertinencia para la institución fueron: el mejoramiento de la infraestructura de computadores, la incorporación de un sistema de gestión de aprendizaje en línea para apoyar los procesos de enseñanza, y la utilización de redes sociales para difundir información relevante a la comunidad educativa de la institución.
Conclusiones: Aplicar MULTIPOL permitió definir los proyectos de desarrollo más relevantes para la institución educativa, es decir, aquellos a los cuales debería prestar más atención para promover su desarrollo.

Palabras clave: plan estratégico informático, institución educativa, MULTIPOL, toma de decisiones, pertinencia.

\section{INTRODUCTION}

Companies require the use of computational tools that facilitate the fulfillment of organizational objectives to allow entering into competitive economies (Panetto and Cecil, 2013). In particular, organizations such as educational institutions use information systems and other aligned technologies, in order to develop strategies that encourage the competitiveness of the company and help them face the challenges of the current context (Sanchez-Puchol, Pastor-Collado, and Borrell, 2017). Taking into account that educational institutions support the development of society, it is essential to increase their level of business and academic knowledge. For this reason, these organizations are implementing information systems capable of establishing a transversal integration for communication, acquisition, and production of information (Martins, Branco, Gonçalves, Au-Yong-Oliveira, Oliveira, Naranjo-Zolotov and Cruz-Jesús, 2019).

These information systems are implemented according to the needs of the institution. For example, administrators use them in the collection and processing of information to support strategic decision-making, whereas the faculty staff need them for managing the students' learning process and the interactions required during the educational process. The application of these systems facilitates accessing, managing, and spreading information throughout the institution, and it also helps reduce work times and guarantee quality reports of different academic dependencies (Shah, 2014). Therefore, the development of strategies focused on improving the management of this resource has become fundamental and required to both achieve a higher level of competitiveness and to improve sustainability practices (Ariani, Gholamzadeh, Mukhtar, Sahran, Abdul and Jaromír, 2017).

Strategic planning is carried out continuously, so that the institution guarantees linking organizational and academic processes with technological growth present in the market. Also, it is possible to align the mission and objectives with the demands of the competitive environment, while having an efficient management among the dependencies (Ariyanto, Budiyanto, and Joko, 2017). However, this planning may lead to projects that exceed the economic, infrastructure, or human resources of the institution because each one entails different duration, complexity, amount of work required, and budget (Zavadskas, Vilutiene, Turskis and Šaparauskas, 2014). Moreover, it is necessary to take into account the uncertainty that comes from a changing market environment and inflexibility that a strategic plan could impose for the organization (Dibrell, Craig and Neubaum, 2014).

One of the methods that help determine the relevance of a project is MULTIPOL. This methodology has been used in research related to decision making. For example, a study carried out in 2018 applied MULTIPOL in the evaluation of the proposals made by the candidates for mayor of Cartagena (Colombia). The work took the proposals related to the promotion of education in the city and evaluated them in order to define which ones were most relevant, and in this way help citizens make the 
best decision regarding the next mayor (Martelo, Hamdan, Jaramillo, 2018). Likewise, other research defines the strategies with the greatest impact to reduce student dropouts, which allows universities to effectively address this phenomenon (Martelo, Herrera, Villabona, 2017). Furthermore, another work analyzes the projects defined in a programmatic proposal of the Program Director of a public university in order to help determine the highest priority projects to be executed in the academic unit and obtain the greatest benefit (Martelo, Jimenez-Pitre, Jaramillo, 2017).

Therefore, the objective of this research is to help determine the relevance of projects defined in a strategic IT plan for its application in the academic and administrative processes of educational institutions. This analysis of projects can be carried out by applying MULTIPOL, which allows supporting decision-making through the evaluation of actions, projects, or strategies in relationship with constraints defined as criteria and policies and taking into account the context of the institution.

\section{METHODOLOGY}

This was a quantitative research, with a descriptive non-experimental cross-sectional design: non-experimental because the variables were studied without manipulation, but only their behavior was observed (Garson, 2013); cross-sectional because the information was collected in a defined and fixed-timed place, based on an established sample (Lee and McKinney, 2013). In addition, the strategic IT plan of the educational institution was detailed in order to determine the relevance of the projects proposed (Babbie, 2011).

The population evaluated consisted of 30 teachers, 3 coordinators, and the rector of the institution named "Cuarta Poza de Manga," located in Turbaco, Bolívar (Colombia). The sample involved the entire population because when applying the collection instrument was access to all participants.

The collection technique was a documentary review where the files contained in the strategic plan were consulted in order to detail the projects included, as shown in Table 1.

Table 1. Projects included in the strategic IT plan of "Cuarta Poza de Manga" Educational Institution.

\section{Projects}

Formal planning of the structure of the academic unit

Improving computer infrastructure

Implementing a software for the management of academic activities in the institution

Incorporating an online learning management system to support teaching processes

Using social media to broadcast relevant information to the community within the institution

\section{Description}

The organizational structure of the academic unit in the institution allows organizing formal information flows and achieving harmony among employees, specifying roles and responsibilities to coordinate and fulfill the strategic objectives of the institution.

Having the computational infrastructure align with what the academic community needs helps increase the use of IT for the training process; it also helps develop skills related to digital literacy. Likewise, the operational activities benefit from the acquisition of equipment for the development of responsibilities, also reducing the consumption of paper.

The implementation of a system to manage information and communication between academic processes within the institution streamlines the activities and procedures of the employees and reduces response times.

This provides advantages, such as facilitating the preparation of students, enhancing transmission of knowledge, obtaining information about the student learning process, applying modular and flexible technology that can be adapted to the needs of each teacher, enhancing digital literacy in students, and having a direct communication channel between students and teachers to solve doubts and share information.

The use of social media as an alternative to support organizational communication and broadcast information allows the institution to announce student acceptance policies, generate channels to encourage parent participation, keep academic calendars updated, and share multimedia content. In addition, it helps in the propagation of the institutional image.

Source: Authors. 
On the other hand, interviews were the instrument applied to obtain information on criteria and policies. This information was used as parameters for the MULTIPOL technique. The approach established in the strategic plan was also taken into account in order to define these parameters. Tables 2 and 3 show this.

MULTIPOL was used as a data analysis method. This method consists of a process of evaluating actions or strategies based on criteria and policies, while taking into account the consensus of a group of experts. In this particular case, the projects established in the strategic plan are analyzed through criteria and policies defined by the directors of the institution in order to rate the relationship between them and define the more relevant projects according to the context of the institution.

A guide model was established to explain the phases of the investigation (Figure 1).

Table 2. Criteria for the evaluation of the projects in the strategic plan.

\begin{tabular}{ll}
\hline \multicolumn{1}{c}{ Criteria } & \multicolumn{1}{c}{ Description } \\
\hline Higher educational quality & To provide better educational quality shown in how the teachers teach. \\
\hline Technological appropriation & $\begin{array}{l}\text { To acquire and adapt technological tools within study lessons and administra- } \\
\text { tive processes. }\end{array}$ \\
\hline Systematization of administrative processes & $\begin{array}{l}\text { To organize administrative processes of the institution to efficiently coordinate } \\
\text { academic management activities. }\end{array}$ \\
\hline Broadcasting information & $\begin{array}{l}\text { According to the number of resources at the economic, infrastructural, and } \\
\text { human level of the educational institution. }\end{array}$ \\
\hline
\end{tabular}

Source: Authors.

Table 3. Policies that define constraints on the projects of the strategic plan.

\section{Policies}

Continuous improvement of the quality system

Continuous teacher training

Information and communication technology support in teaching

Association with organizational processes

\section{Description}

To establish standard activities that allow growth in the quality of academic and administrative processes.

To define strategies that support the pedagogical and professional development of teachers on an ongoing basis.

To incorporate information and communication technologies in the academic activities of teachers in order to improve the teaching methodologies applied in class.

The strategies must be consistent with the academic and administrative activities and processes of the institution in order to support achieving the organizational objectives.

Source: authors.
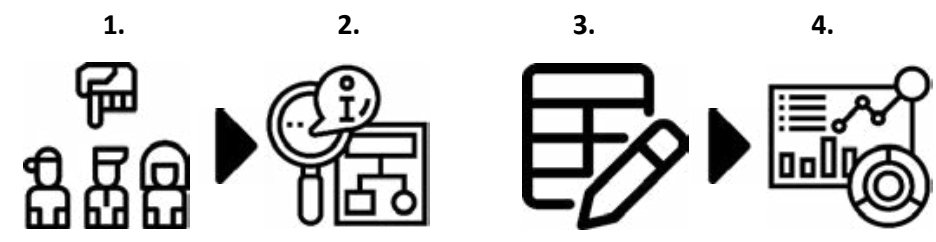

Figure 1. Conceptual model proposed to define the phases of the investigation.

Source: Authors. 
Phase 1: Selecting the group of experts. People with academic and administrative expertise within the educational institution were asked to participate in order to define the parameters required for using MULTIPOL. The teachers and administrative staff of the institution "Cuarta Posa de Manga" were chosen as a group of experts for the study because they are the actors involved in the management and teaching-learning processes.

Phase 2: Gathering information. The opinion of the group of experts was taken into account, and the data relevant to their knowledge of the strategic plan was consulted in order to define the criteria and policies that would serve to evaluate the projects contained in the plan and establish their relevance with the objectives and resources of the institution. Therefore, the actions were determined according to the requirements of the MULTIPOL technique, which contains the following variables: short name, long name, and description (Table 4).

Likewise, the criteria and policies were established based on the same parameters of the actions, but MULTIPOL requires that these variables contain an attribute of weight, which determines the relevance of the criteria for the projects assessed. Tables 5 and 6 show this new attribute.

Table 4. Actions adjusted to the parameters of the MULTIPOL technique.

\begin{tabular}{|c|c|c|}
\hline Long name & Short name & Description \\
\hline $\begin{array}{l}\text { Formal planning of the or- } \\
\text { ganizational structure of the } \\
\text { academic unit }\end{array}$ & FPSU & $\begin{array}{l}\text { The organizational structure of the academic unit in the institution allows } \\
\text { organizing formal information flows and achieving harmony among em- } \\
\text { ployees, specifying roles and responsibilities to coordinate and fulfill the } \\
\text { strategic objectives of the institution. }\end{array}$ \\
\hline $\begin{array}{l}\text { Improving of the computer } \\
\text { infrastructure }\end{array}$ & $\mathrm{ICl}$ & $\begin{array}{l}\text { Having the computational infrastructure align with what the academic com- } \\
\text { munity needs helps increase the use of IT for the training process; it also } \\
\text { helps develop skills related to digital literacy. Likewise, the operational ac- } \\
\text { tivities benefit from the acquisition of equipment for the development of } \\
\text { responsibilities, also reducing the consumption of paper. }\end{array}$ \\
\hline $\begin{array}{l}\text { Implementing a software for } \\
\text { the management of academic } \\
\text { activities in the institution }\end{array}$ & ISMA & $\begin{array}{l}\text { The implementation of a system to manage information and communication } \\
\text { between academic processes within the institution streamlines the activities } \\
\text { and procedures of the employees and reduces response times. }\end{array}$ \\
\hline $\begin{array}{l}\text { Incorporating an online lear- } \\
\text { ning management system to } \\
\text { support teaching processes }\end{array}$ & ISMT & $\begin{array}{l}\text { This provides advantages, such as facilitating the preparation of students, } \\
\text { enhancing transmission of knowledge, obtaining information about the stu- } \\
\text { dent learning process, applying modular and flexible technology that can be } \\
\text { adapted to the needs of each teacher, enhancing digital literacy in students, } \\
\text { and having a direct communication channel between students and teachers } \\
\text { to solve doubts and share information. }\end{array}$ \\
\hline $\begin{array}{l}\text { Using social media to broadcast } \\
\text { relevant information to the } \\
\text { community within the institu- } \\
\text { tion }\end{array}$ & SNIE & $\begin{array}{l}\text { The use of social media as an alternative to support organizational com- } \\
\text { munication and broadcast information allows the institution to announce } \\
\text { student acceptance policies, generate channels to encourage parent parti- } \\
\text { cipation, keep academic calendars updated, and share multimedia content. } \\
\text { In addition, it helps in the propagation of the institutional image. }\end{array}$ \\
\hline
\end{tabular}

Source: Authors. 
Table 5. Criteria adjusted to the parameters of the MULTIPOL technique.

\begin{tabular}{lccl}
\hline \multicolumn{1}{c}{ Long name } & Short name & Weight & \multicolumn{1}{c}{ Description } \\
\hline Higher educational quality & HEQ & 1 & $\begin{array}{l}\text { To provide better educational quality shown in how the teachers } \\
\text { teach. }\end{array}$ \\
\hline Technological appropriation & TA & 1 & $\begin{array}{l}\text { To acquire and adapt technological tools within study lessons } \\
\text { and administrative processes. }\end{array}$ \\
$\begin{array}{l}\text { Systematization of administrative } \\
\text { processes }\end{array}$ & SAP & 1 & $\begin{array}{l}\text { To organize administrative processes of the institution to effi- } \\
\text { ciently coordinate academic management activities. }\end{array}$ \\
\hline Available resources & AR & 1 & $\begin{array}{l}\text { According to the number of resources at the economic, infras- } \\
\text { tructural, and human level of the educational institution. }\end{array}$ \\
\hline Broadcasting information & DI & 1 & $\begin{array}{l}\text { To communicate information related to academic activities and } \\
\text { resources within the institutional work, as well as the impact the } \\
\text { institution has on the municipality, the region, and the country. }\end{array}$ \\
\hline
\end{tabular}

Source: Authors.

Table 6. Policies adjusted to the parameters of the MULTIPOL technique.

\begin{tabular}{lccl}
\hline \multicolumn{1}{c}{ Long name } & Short name & Weight & \multicolumn{1}{c}{ Description } \\
\hline $\begin{array}{l}\text { Continuous improvement of the } \\
\text { quality system }\end{array}$ & CIQS & 1 & $\begin{array}{l}\text { To establish standard activities that allow growth in the quality of } \\
\text { academic and administrative processes. }\end{array}$ \\
\hline Continuous teacher training & CTT & 1 & $\begin{array}{l}\text { To define strategies that support the pedagogical and professio- } \\
\text { nal development of teachers on an ongoing basis. }\end{array}$ \\
\hline $\begin{array}{l}\text { Information and communication } \\
\text { technology support in teaching }\end{array}$ & ICTT & 1 & $\begin{array}{l}\text { To incorporate information and communication technologies in } \\
\text { the academic activities of teachers in order to improve the tea- } \\
\text { ching methodologies applied in class. }\end{array}$ \\
\hline $\begin{array}{l}\text { Association with organizational } \\
\text { processes }\end{array}$ & AOP & 1 & $\begin{array}{l}\text { The strategies must be consistent with the academic and admi- } \\
\text { nistrative activities and processes of the institution in order to } \\
\text { support achieving the organizational objectives. }\end{array}$ \\
\hline
\end{tabular}

Source: Authors.

Phase 3: Definition of the relevance of the projects. MULTIPOL was applied to the projects contained in the strategic plan of the institution, and the criteria and policies served as constraining factors for each situation. This process resulted in tables and graphs that show the relationship between actions and the other variables, their compatibility, and the probability to succeed.

Phase 4: Analysis and selection of projects. The results obtained after applying MULTIPOL are examined with the institution administrative staff since they are in charge of selecting the projects to be executed for improving efficiency of academic and administrative processes. MULTIPOL presents graphs that show the behavior of the actions concerning the criteria and policies to determine their relevance for the institution.

\section{RESULTS}

To define the relevance of the projects, the variables required were submitted, and the resulting tables and graphs were displayed. Table 7 shows the relationship between actions and policies.

The average obtained for each project is shown and indicates the impact of its implementation on the institution's processes. Likewise, a graph called Profile Map was obtained, which presents the behavior of the relationship between actions and policies in order to establish priorities regarding the projects that are more closely related to the policies that govern the institution (shown in Figure 2).

On the other hand, MULTIPOL also provided a graph known as Sensitivity Classification Map, which represents the success probability of the 
Table 7. Evaluation of actions regarding the policies of the institution.

\begin{tabular}{ccccccc}
\hline Actions/Policies & CIQS & CTT & ICTT & AOP & Average & Standard deviation \\
\hline FPSU & 14,3 & 14,4 & 14,4 & 14,9 & 14,5 & 0,2 \\
\hline ICI & 16,1 & 16,4 & 16,1 & 16,1 & 16,2 & 0,1 \\
\hline ISMA & 15,2 & 15,4 & 15,3 & 15,2 & 15,3 & 1 \\
\hline ISMT & 16,4 & 16,9 & 16,5 & 16,5 & 16,5 & 0,2 \\
\hline SNIE & 15,8 & 16 & 16 & 15,6 & 15,9 & 0,2 \\
\hline
\end{tabular}

Source: Authors.

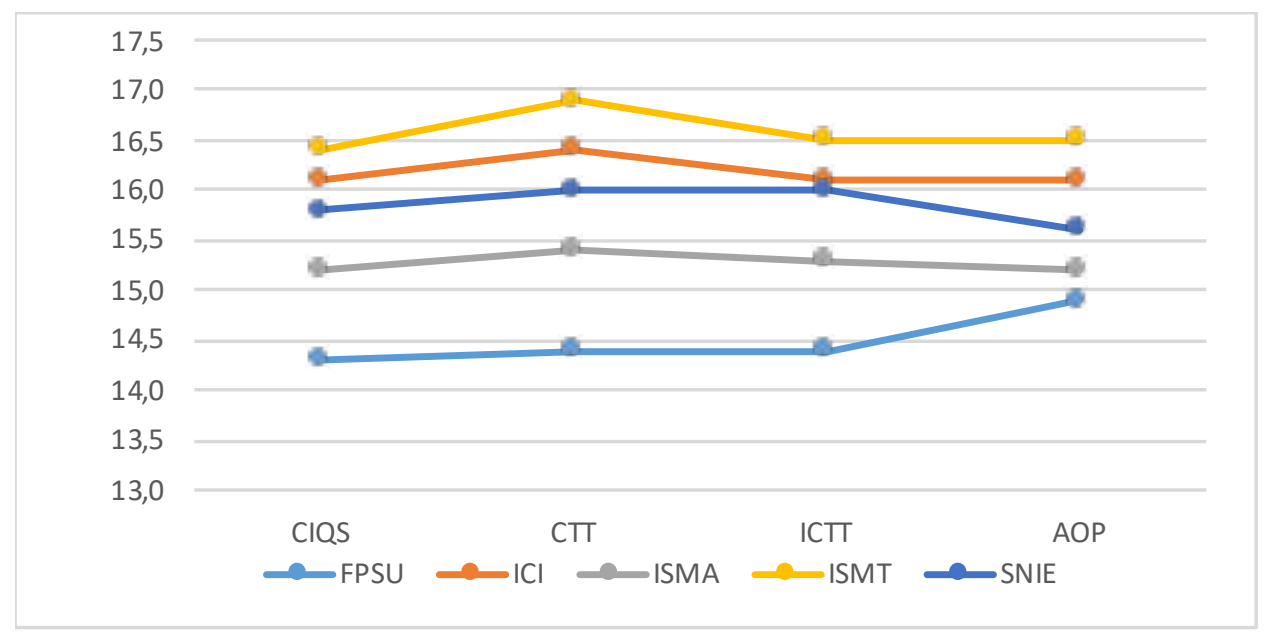

Figure 2. Profile Map of action evaluation in relationship with policies.

Source: Authors.

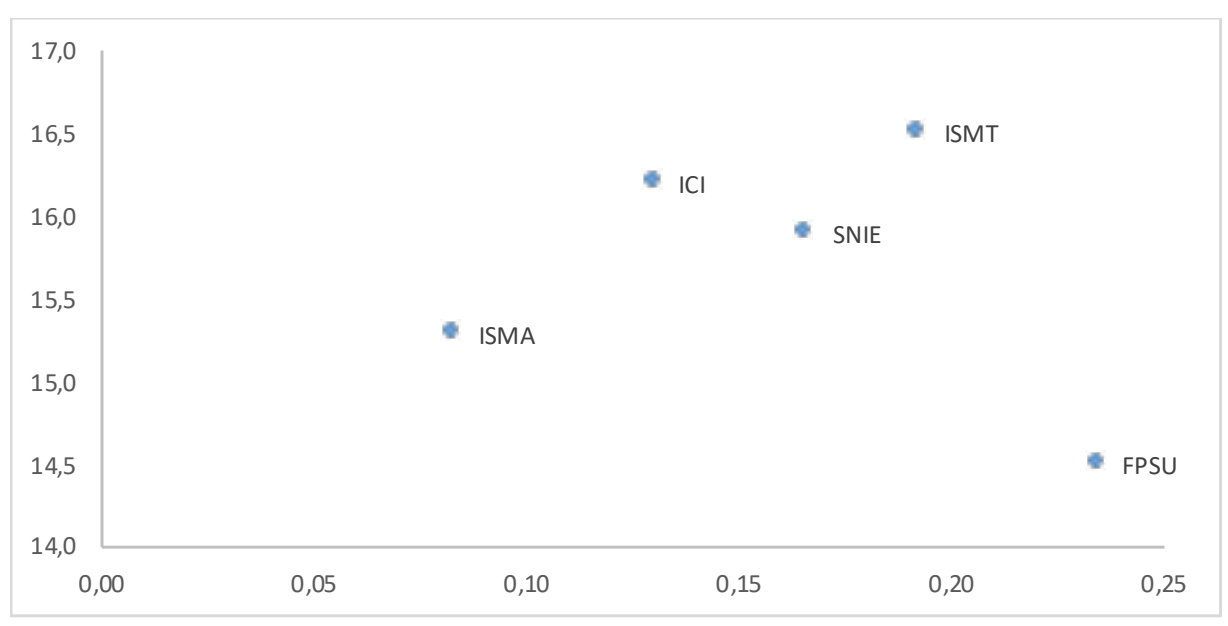

Figure 3. Sensitivity classification map of the evaluation of actions in relationship with policies.

Source: Authors. 
projects based on the effectiveness of their implementation in "Cuarta Posa de Manga." The one furthest left is the one with greatest probability to succeed, while the projects with high effectiveness are those located highest on the graph, as shown in Figure 3.

As seen in the previous graph, the most effective projects for the institution are ISMT and ICI, while those with the highest probability of success are ISMA and ICI. Thus, the project most favorable for the institution is ICI (Improvement of computing infrastructure), followed by ISMT (Incorporating an online learning management system to support teaching processes), SNIE (Using social media to broadcast relevant information to the community within the institution), ISMA (Implementing a software for managing the academic area of the institution), and FPSU (Formal planning of the organizational structure of the academic unit). This result is similar to the study carried out by (Pucciarelli and Kaplan, 2016), where it is stated that social networks and viral marketing are essential for the development of educational institutions, so that they can obtain greater visibility, reputation, and prestige with which compete with other organizations, as well as focus their efforts on developing technology to eliminate barriers that may arise in the inclusion of new forms of teaching.

$\mathrm{ICl}$ is established as the project with the greatest relevance because it supports the effective fulfillment of the other projects. In addition, it satisfies the needs of appropriation of information and communication technologies in the academic and administrative processes of the institution "Cuarta Poza de Manga," since having a computational infrastructure with sufficient characteristics would guarantee an improvement in the activities carried out by teachers and administrative staff.

This result is similar to the research carried out by Bozalek, Ng'ambi, and Gachago (2013), which determined that in order to achieve the acceptance and use of technology, the institution must define strategies focused on the creation of propitious spaces for this purpose; furthermore, it is necessary to implement policies that promote continuous improvement of information technologies in educational establishments.

\section{CONCLUSIONS}

The most relevant project for the educational institution was the "Improvement of the computer infrastructure" because it supports the effective fulfillment of other projects and guarantees the optimization of academic and administrative processes.

Other projects that are taken into account for the development of the institution were "Incorporating an online learning management system to support teaching processes," "Using social media to broadcast relevant information to the community within the institution," "Implementing a software for the management of the academic area," and "Formal planning of the organizational structure of the academic unit," which are organized by their positive impact on the educational institution.

The project with the highest probability of success was "Implementing a software for the management of the academic area." This should be taken as the first project to implement if an anomaly with any resource or process in a specific area occurs.

\section{REFERENCES}

Ariani, F., Gholamzadeh, A., Mukhtar, M., Sahran, S., Abdul, S. y Jaromír, J. (2017). Strategic alignment between sustainability and information systems: A case analysis in Malaysian Public Higher Education Institutions. Journal of Cleaner Production, 168, 263270. https://doi.org/10.1016/j.jclepro.2017.09.021

Ariyanto, A., Budiyanto, D., y Joko, A. (2017). Strategic Planning of Information System (Case Study: Ministry of Religious Affairs in Southwest Sumba). International Journal of Computer Engineering and Information Technology, 9(7), 143-149.

Babbie, E. (2011). The basics of social research, 5th edition. Estados Unidos: Wadsworth Cengage learning. Bozalek, V., Ng'ambi, D. y Gachago, D. (2013). Transforming teaching with emerging technologies: Implications for higher education institutions. South African Journal of Higher Education, 27(2), 419-436. 
Dibrell, C., Craig, J. y Neubaum, D. (2014). Linking the formal strategic planning process, planning flexibility, and innovativeness to firm performance. Journal of Business Research, 67, 2000-2007. https://doi. org/10.1016/j.jbusres.2013.10.011

Garson, G.D. (2013). Research design. Asheboro, USA: Statistical Publishing Associates

Lee, M. y McKinney, J. (2013). Understanding and applying research design. Hoboken, New Jersey: John Wiley \& Sons, Inc.

Martelo, R., Hamdan, M. y Jaramillo, J. (2018). Aplicación de Multipol para determinar mejor propuesta en educación de candidatos a la alcaldía de Cartagena. Revista AGLALA, 9(1), 418-429.

Martelo, R., Herrera, K. y Villabona, N. (2017). Estrategias para disminuir la deserción universitaria mediante series de tiempo y multipol. Revista Espacios, 38(45), 25.

Martelo, R., Jimenez-Pitre, I. y Jaramillo, J (2017). Definición de proyectos para ejecutar propuestas programáticas en unidades académicas de Universidades Públicas a través de la técnica MULTIPOL. Revista Espacios, 38(20), 24.

Martins, J., Branco, F., Gonçalves, R., Au-Yong-Oliveira, M., Oliveira, T., Naranjo-Zolotov, M. y Cruz-Jesus, F. (2019). Assessing the success behind the use of education management information systems in higher education. Telematics and Informatics, 38, 182-193. https://doi.org/10.1016/j.tele.2018.10.001

Panetto, H. y Cecil, J. (2013). Information systems for enterprise integration, interoperability and networking: theory and applications, Enterprise Information Systems, 7(1), 1-6. https://doi.org/10.1080/175175 75.2012 .684802

Pucciarelli, F. y Kaplan, A. (2016). Competition and strategy in higher education: Managing complexity and uncertainty. Business Horizons, 59(3), 311-320. https://doi.org/10.1016/j.bushor.2016.01.003

Sanchez-Puchol, F., Pastor-Collado, J. y Borrell, B. (2017). Towards an Unified Information Systems Reference Model for Higher Education Institutions. Procedia Computer Science, 121, 542-553. https://doi. org/10.1016/j.procs.2017.11.072

Shah, M. (2014). Impact of Management Information Systems (MIS) on School Administration: What the Literature Says. Procedia-Social and Behavioral Sciences, 116, 2799-2804. https://doi.org/10.1016/j. sbspro.2014.01.659

Zavadskas, E.K., Vilutiene, T., Turskis, Z. y Šaparauskas, J. (2014). Multi-criteria analysis of Projects' performance in construction. Archives of Civil and Mechanical Engineering, 14(1), 114-121. https://doi. org/10.1016/j.acme.2013.07.006

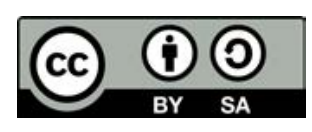

Tecnura • p-ISSN: 0123-921X • e-ISSN: 2248-7638 • Vol. 24 No. 66 • Octubre - Diciembre de $2020 \bullet$ pp. 76-84 